\title{
СЛУЖБА ПРОБАЦИИ КАК ФОРМА СОЦИАЛЬНО-ПЕДАГОГИЧЕСКОЙ РАБОТЫ С ПРАВОНАРУШИТЕЛЯМИ
}

Гусак А. П.

B статье рассматриваются вопросы становления службы пробации в Украине как новой и современной парадигмы перевоспитания правонарушителей. Она представляется как альтернативная форма ресоциализации правонарушителей относительно пенитенциарной системы постсоветского образца. Акцентируется внимание на экономической и социально-педагогической составляющих современной службы пробации в Украине. Выделяются проблемы подготовки специалистов в высшей школе на этапе становления новой службы.

Ключевые слова: пробация, служба пробации, несовершеннолетние осужденные, ресоциализация, социально-педагогические аспекты пробации.

У статmі розглядаються питання становлення служби пробації в Україні як нової та сучасної парадигми перевиховання правопорушників. Вона представляється як альтернативна форма ресоціалізації правопорушників щодо пенітенціарної системи пострадянського зразка. Акцентується увага на економічному і сочіально-педагогічному складниках сучасної служби пробації в Україні. Виділяються проблеми підготовки фахівців у вищій школі на етаni становлення нової служби.

Ключові слова: пробація, служба пробації, неповнолітні засуджені, ресоціалізація, соціально-педагогічні аспекти пробаціі.

The article examines the issues of the development the probation service in Ukraine as a new modern paradigm in the rehabilitation of offenders. It is presented as an alternative form of the resocialization of offenders to the penitentiary system of the post-Soviet model. Attention is focused on the economic and social-pedagogical components of the modern probation service in Ukraine. The problems of training specialists in higher educational establishments at the stage of the formation of a new probation service are singled out in the given article. Higher educational institutions of Ukraine in the field of law and social work are involved in training probation specialists. So, for example, at the Lesya Ukrainka East European National University, the specialization "Specialist in social work with probation subjects" was introduced in the specialty "Social Work". It is emphasized that the adoption of the Law of Ukraine "On Probation" is the first step towards international standards in the field of justice. The effectiveness of the probation service largely depends on the further steps of its development, on their compliance with the European principles of probation, on supporting these steps at the political level, on promoting public understanding and perception of the positive role of probation. To ensure the functioning of the probation service, the experts of the European Union project "Support to reforms in the justice sector of Ukraine" are developing a strategy for the development of probation in Ukraine, which will allow the implementation of the above ideas within the framework of European standards. Probation in Ukraine is a relatively new institution and is

Гусак А. П., 2019 aimed at solving social problems that the modern prison system is not able to solve.

Key words: probation, probation service, juvenile convicts, resocialization, socially-pedagogical aspects of probation.

Постановка проблемы и ее актуальность. Пробация в Украине является относительно новым институтом и направлена на решение задач социального характера, которые современная пенитенциарная система не способна решить. Постсоветская система перевоспитания носит больше карательный, чем воспитательный, ресоциализационный характер. В то же время опыт европейских государств подтверждает, что пробация открывает новые механизмы работы с правонарушителями. Реализация инициатив международных проектов является важным стартом и способствует практическому воплощению положений Закона Украины «О пробации» в задачах ресоциализационого характера. Внедрение в Украине полноценного института пробации базируется на международно-правовых стандартах прав человека, поскольку цивилизационный опыт в этом плане имеет глубокие исторические корни.

Анализ последних исследований и публикаций. Вопросы внедрения и применения пробации в отношении несовершеннолетних правонарушителей поднимают в своих работах А. Бец [3], Е. Змановская [5], Н. Татт [10], К. Ханвей и Т. Филпот [1], Д. Ягунов [13] и др. Функции службы пробации выделяют Д. Ягунов [14], Н. Шарова [12], Д. Витфилд [2].

Цель статьи - исследовать состояние реформирования пенитенциарной системы Украины в направлении создания на базе уголовно-исполнительной инспекции службы пробации, проанализировать основные этапы ее внедрения в Украине, выявить проблемы и пути их решения по организации службы пробации в нашем государстве.

Изложение основного материала. Первые механизмы пробации фактически были внедрены усилиями американского филантропа Джона Августа в 1841 году. На формальном уровне система пробации была введена в штате Массачусетс в 1869 году.

Европейский опыт начинается с Британии, где в 1887 году был принят Закон «О пробации преступников, совершивших преступление впервые» (The Probation of First Offenders Act). Он позволял освобождать некоторые категории мелких преступников «по пробации» (“on probation”). Этот закон и опыт работы послужили принятию в 1907 году в Англии и Уэльсе другого нормативного акта, который включал механизмы его реализации. Это был Закон «О пробации преступников» (The Probation of Offenders Act). 
В настоящее время в Украине введение службы пробации носит скорее формально-юридический характер регулирования сложных общественных отношений. Все из-за отсутствия механизмов социальной работы с преступниками и концептуально-идеологического обоснования новой институции. Концептуальное видение современной правоохранительной системы - это когда наказание ни в коей мере не должно носить характер мести. Наказание, которое суд определяет от имени государства, должно способствовать восстановлению разрушенного правонарушением равновесия - социальной справедливости, которая лежит в основе любого правового государства и характеризует развитый, организованный общественный строй.

Наказание определяется в зависимости от того, насколько опасным было совершенное правонарушение, поэтому бывает разным. Если допустить, что наказание строже, чем правонарушение, то его применение не восстанавливает социальную справедливость, поэтому выбор соответствующего наказания имеет большое значение (Лейлен, 1996) [6].

Однако определением наказания процесс не заканчивается. Назначенное наказание необходимо еще и выполнить. Процесс исполнения наказания также важен, как и его определение. В основе исполнения наказания лежат две составляющие - карающая и коррекционная.

К сожалению, сегодня в процессе исполнения наказания абсолютно необоснованно наибольший акцент делается на карающийэлемент, приэтом забывается второй - воспитательный. Воспитательный элемент наполняет содержанием суть наказания и устраняет причины, послужившие основой совершения правонарушения.

Создание службы пробации в Украине свидетельствует о становлении государства, в котором система наказаний не должна носить характер мести, а показывать, что каждый человек для общества ценен, а его судьба государству важна.

Создание службы пробации свидетельствует о том, что правонарушитель не списывается как потерянный для общества, а реинтегрируется в общество. Коррекция социального поведения в тюрьмах, а также реинтеграция освобожденных из тюрем является обязательной ответственностью государства за членов общества [12, с. 65-68].

Принудительные работы, отсрочка выполнения приговора при условии строгого контроля является гарантией того, что государство не ограничивает свободу людей без необходимости. Здесь на главное место выходит процесс пробации. Опыт других государств показывает, что пробация эффективна, если методы ее работы надежны и проверены [14].

В 2015 году Украина сделала значительный прорыв в реформировании уголовного законодательства. В августе 2015 года вступил в силу Закон Украины «О пробации». Внедрение службы пробации в Украине это не только шаг навстречу европейским стандартам соблюдения прав человека, но и значительная перспектива исправления правонарушителей без заключения.

Служба пробации призвана решать не только воспитательные, ресоциализационные, социально-педагогические проблемы, но и финансовые. Понятно, что уголовное наказание с точки зрения финансирования процесса исполнения наказания дорого обходится для государства и для налогоплательщиков. Кроме того, финансирование требуется и после отбывания наказания. Здесь речь идет о расходах, связанных с возвращением людей в общество из мест лишения свободы. И надо сказать, что расходы на содержание заключенных растут с каждым годом.

Доказано, что наказания, не связанные с лишением свободы, являются эффективными в предотвращении преступности, поскольку позволяют избежать вредных последствий пребывания человека в тюрьме и сэкономить государственные средства [7, с. 37-40].

Процесс внедрения службы пробации в Украине это очень важный шаг в направлении евроинтеграции и построения гражданского общества, в котором соблюдаются права человека.

Определяя сущность понятия «пробация», следует указать на то, что это «метод работы с преступниками» [6] (om англ. “Probation” - «испытание, пробация» - форма условного осуждения, получившая широкое распространение в практике судов Великобритании, США и других стран [9].

Понятие пробации дано в статье 2-1 Закона Украины «О пробации»: «Пробация - система надзорных и социально-воспитательных мер, применяемых по решению суда и в соответствии с законом к осужденным, выполнение определенных видов уголовных наказаний, не связанных с лишением свободы, и обеспечение суда информацией, характеризующей обвиняемого».

Сегодня понятие «пробация» используется в нескольких значениях: 1) состояние, в котором находится преступник в течение определенного срока (преступник (probationer) находится «на пробации», то есть под пробационным наблюдением (on probation, under probation)) [15]; 2) как концепция социальной работы с правонарушителями и другими социально уязвимыми группами; 3) как орган государственной власти (служба); 4) как специфический процесс выполнения альтернативных наказаний; 5) как наказание с отсрочкой исполнения; 6) как соединительное звено между уголовным процессом, выполнением наказаний и социальной работой [13, с. 289].

Социально-педагогические аспекты пробации включают индивидуальный подход к каждому осужденному, изучение и сбор личностных характеристик и персональных данных, рассмотрение проблем и потребностей, выявление причин и социальных обстоятельств, мешающих социальной адаптации осужденного, составление соответствующего плана работы по его реабилитации (плана надзора). План надзора включает в себя как требования к поведению осужденного, так и меры, направленные на оказание ему социальной помощи и социальных услуг (консультативных, педагогических, психологических, услуг по трудоустройству, переселению, бытовому обустройству и т.д.).

В рамках проведения реформ в системе исполнения наказаний в Украине была ликвидирована Государственная пенитенциарная служба. Создано новое юридическое лицо общественного права.

Правопреемниками ликвидированного органа стали межрегиональные управления по вопросам исполнения уголовных наказаний и пробации Министерства юстиции. Но, откровенно говоря, система наказаний, не связанная с лишением свободы, была в нашей стране и раньше. Есть наказания, связанные, напри- 
мер, с запретом занимать определенные должности и заниматься определенной деятельностью, наказания в виде исправительных или общественных работ. Эти наказания применялись и до того, как была введена служба пробации в Украине.

Но в зарубежных странах существует иной подход к альтернативным наказаниям. Альтернативное наказание - это только часть системы пробации. Человек не попадает в места лишения свободы, ему выносят приговор и оставляют в социуме.

Согласно Закону Украины «О пробации» предусмотрены три таких вида пробации: досудебная пробация обеспечение суда информацией, характеризующей личность обвиняемого в совершении правонарушения, с целью изучения его жизни для принятия судом справедливого решения о мере его ответственности (составление досудебного доклада); наблюдательная пробация - осуществление надзорных и социально-воспитательных мероприятий, т. е. предоставление психологической, консультативной и других видов помощи, содействие трудоустройству, привлечение к обучению, участие в воспитательных мероприятиях и социально полезной деятельности, проведение индивидуально-профилактической работы в отношении лица, к которому применяется пробация; пенитенциарная пробация - это помощь лицу, которое готовится к освобождению из мест лишения свободы, в трудовом и бытовом смысле, госпитализация в учреждения здравоохранения и содействие в адаптации к жизни в обществе.

У нас в стране уже внедрен досудебный доклад, который относится к досудебной пробации. Пробация начинает действовать с момента получения судом материалов о преступлении для рассмотрения. Досудебный доклад - это определенный документ, который должен составлять работник пробации в сотрудничестве с обвиняемым и подавать его в суд для вынесения справедливого приговора. Он составляется на основании оценки риска осуществления лицом повторного правонарушения. В странах, где работает служба пробации, есть определенные сферы жизнедеятельности, которые оказывают большое влияние на вероятность рецидива.

Работник пробации дает оценку ситуации, устанавливает сферы жизнедеятельности, определяет риск. Он видит, есть ли проблемы, и определяет, какие именно. Работники пробации - это особая категория персонала уголовной юстиции (за рубежом их называют социальными юристами). Это не просто специалисты с юридическим образованием, а юристы, имеющие глубокие знания в сфере социальной работы.

В практике социально-педагогического воздействия часто используют пробационные программы. Пробационные программы - это специальные программы социально-психологического или психо-коррекционного направления, которые суд обязывает пройти для того, чтобы человек изменил свое поведение, свое отношение к окружающему миру, свой внутренний мир.

В мире уже давно считается не только обязательным прохождение лечебных программ, связанных С зависимостями от алкоголя и наркотиков, но и программ, направленных на изменение внутреннего мира человека, имеющего существенное влияние на его поведение [11, с. 611]. Эти программы начали действовать в Украине с 1 января 2018 года после утверждения их в установленном законодательством порядке.
Следующим видом является наблюдательная пробация, которая предусматривает пробационный надзор и работу с лицами, осужденными к наказаниям, не связанным с лишением свободы. Эта работа заключается в проведении оценки и составлении плана воспитательной работы. Этот процесс внедрен в Украине и начинает работать. Сейчас отрабатываются формы и методы мониторинга качества выполнения этих мероприятий.

Вопросами подготовки специалистов в области пробации занимаются высшие учебные заведения Украины в сфере права и социальной работы. Например, в Восточноевропейском национальном университете имени Леси Украинки в рамках специальности «Социальная работа» введена специализация «Специалист социальной работы с субъектами пробации». При этом изучаются основные механизмы становления и правового регулирования пробации в Украине на основе системного анализа нормативно-правового обеспечения пробации и компетентностного подхода к определению качества подготовки социальных работников, способных работать с субъектами пробации. Обращается внимание на повышение уровня профессиональной компетентности будущих социальных работников, уровня их готовности умело и профессионально выполнять свои обязанности, на овладение современными теоретическими и прикладными знаниями по анализу и применению норм права в работе с субъектами пробации, на дальнейший профессиональный рост в условиях совершенствования правового регулирования пробации в Украине.

Подготовка таких специалистов осуществляется с целью усвоения студентами теоретических основ становления пробации и законодательного обеспечения организации служб пробации в Украине, формирования основных умений и навыков применения норм права в социально-воспитательной деятельности с субъектами пробации.

Обращается внимание на такие аспекты пробации, как характеристика исторических предпосылок и основных этапов становления пробации; раскрытие содержания основных международных и отечественных нормативно-правовых документов, обеспечивающих деятельность служб пробации; изучение опыта применения ведущих моделей пробации в отдельных зарубежных странах; анализ норм правовых документов, регламентирующих становление и организацию системы пробации в Украине; освещение правовых основ социально-воспитательной работы с субъектами пробации в Украине.

Выпускники должны знать современные тенденции совершенствования системы пробации в разных странах, общие и отличительные черты различных видов нормативных документов относительно принципов и закономерностей организации пробации, особенности трансформации международного опыта организации системы пробации в Украине, принципы построения системы пробации на основе норм действующего законодательства, особенности содержания нормативно-правового сопровождения каждого вида пробации, роль социальной работы в пробационной деятельности, перспективы реформирования пенитенциарной системы и развития пробации в Украине.

Кроме того, они должны уметь применять нормы действующего законодательства в своей профессиональной деятельности, логично толковать нормы права 
тех документов, которые необходимы в деятельности, выделять из содержания документов вышестоящего органа те, которые имеют обязательный характер исполнения, а какие рекомендательный, разрабатывать на основе типовых документов нормативные документы для организации деятельности службы пробации, внедрять изменения в законодательстве при разработке должностных инструкций, положений и пр., выполнять свои должностные обязанности в соответствии с нормами законодательства, строить свои взаимоотношения с другими субъектами пробации в соответствии с нормами действующего законодательства, осуществлять социально-правовое сопровождение субъектов пробации, повышать свой профессиональный уровень в соответствии с обстоятельствами.

Выводы. Пробация не является абсолютно новым революционным путем, в том числе и в Украине. Это цивилизационный путь, который доказал свою эффективность во всем мире именно с точки зрения безопасности общества и предупреждения совершения повторных правонарушений.

Принятие Закона Украины «О пробации» - это первый шаг на пути к международным стандартам в сфере юстиции. Эффективность службы пробации в значительной степени зависит от дальнейших шагов ее развития, от их соответствия европейским принципам пробации, от поддержки этих шагов на политическом уровне, содействия общественному пониманию и восприятию положительной роли пробации. Для обеспечения функционирования службы пробации специалисты проекта Европейского Союза «Поддержка реформ в сфере юстиции Украины» разрабатывают стратегию развития пробации в Украине, которая позволит реализовать вышеописанные идеи в рамках европейских стандартов.

\section{Литература}

1. Альтернатива тюремному заключению: практика социальной работы / под ред. К. Ханвея и Т. Филпота. Амстердам. Киев : Логос, 1996. 256 с.

2. Вітфілд Д. Вступ до служби пробації : монографія. Видання 2-ге, перероб. та доповн. Київ : Атіка, 2004.

3. Впровадження альтернативних видів кримінальних покарань в Україні : посібник / за ред. О.В. Беци. Київ : МП «Леся», 2003. 116 c.
Протидія злочинності: проблеми практики та науково-методичне забезпечення

4. Економічні та соціальні чинники освіти у виправних закладах кримінально-виконавчої системи України / О.Г. Гончаренко, Г.В. Кравчук. Вісник Житомирського державного технологічного університету. Серія «Економічні науки». 2016. № 3. URL: http://nbuv.gov.ua/ UJRN/Vzhdtu_econ_2016_3_10.

5. Змановская Е.В. Девиантология (Психология отклоняющегося поведения) / Е.В. Змановская. Москва : Издательский центр «Академия», 2003. 288 с.

6. Лейленд П. Кримінальне право: злочин, покарання, судочинство (Англійській підхід) / пер. з англ. Київ : Основа, 1996. 207 с.

7. Леленталь С., Вежбицкий П. Исполнения наказаний в виде лишения свободы в европейских социалистических государствах. Москва : Юридическая литература, 1978.

8. На скільки утримання одного злочинця перевищує денний прожитковий мінімум українця. URL: http://24tv. ua/na_skilki_utrimannya_odnogo_zlochintsya_perevishhuye_ denniy_prozhitkoviy_minimum_ukrayintsya_n679607.

9. Никифоров Б.С., Решетников Ф.М. Современное американское уголовное право. Москва, 1990.

10. Татт Н. Альтернатива тюремному заключению : практика социальной работы / под ред. К. Ханвея и Т. Филпота. Амстердам. Киев : Логос, 1996. 256 с.

11. Ферри Э. Уголовная социология. Москва : Инфра-М, 2009.

12. Шаровая Н., Ягунов Д. Використання механізмів відновного правосуддя при виконанні альтеративних покарань: вітчизняні реалії та деякий зарубіжний досвід. Впровадження відновного правосуддя в Україні: висновки та перспективи : матеріали міжнарод. конф. 20-21.04.2006 р., М. Київ.

13. Ягунов Д. Пенітенціарна система України: історичний розвиток, сучасні проблеми та перспективи реформування : монографія. Черкаси, 2006.

14. Ягунов Д.В. Служба пробації: концепція, принципи діяльності, організаційна структура : конспект лекцій. Одеса : ОРІДУ, 2006. 74 с.

15. International Centre for Prison Studies. URL: http://www.prisonstudies.org/info/worldbrief/wpb_stats. phpMarch16,2014.

Гусак А. П., кандидат юридических наук, доцент, доцент кафедры уголовного права и процесса Восточноевропейского национального университета имени Леси Украинки 